\title{
Адвентивная травянистая флора Ботанического сада Южного федерального университета
}

\section{Adventive grassy flora of the Botanical garden of Southern Federal University}

\author{
Шмараева А. Н., Шишлова Ж. Н., Кузьменко И. П. \\ Shmarayeva A. N., Shishlova Zh. N., Kuzmenko I. P. \\ Ботанический сад Южного федерального университета, г. Ростов-на-Дону, Россия. E-mail: anshmaraeva@sfedu.ru \\ Botanical garden of Southern Federal University, Rostov-on-Don, Russia
}

\begin{abstract}
Peфepam. В статье приводится видовой состав и краткий анализ травянистой фракции адвентивной флоры Ботанического сада Южного федерального университета (БС). Адвентивная травянистая флора насчитывает 66 видов семенных растений из 25 семейств и 55 родов, что составляет 9,1\% от общего состава дикорастущей флоры БС и 25,0 \% от состава синантропной флоры БС. Выявлен новый для Ростовской области адвентивный вид - Parietaria chersonensis (Lang et Szov.) Dörfl.
\end{abstract}

Ключевые слова. Адвентивная флора, Ботанический сад ЮФУ, первичный ареал, степень натурализации, чужеродный вид.

Summary. The specific structure and the short analysis of grassy fraction of adventive flora of the Botanical garden of Southern Federal University (BS) is given in article. Adventive grassy flora contains 66 species of seed plants from 25 families and 55 genuses that makes $9.1 \%$ of the general structure of wild-growing flora of BS and $25.0 \%$ of structure of sinanthropic flora of BS. The new adventive species to the Rostov region, - Parietaria chersonensis (Lang et Szov.) Dörfl., - was revealed.

Key words. Adventive flora, alien species, Botanical garden SFU, naturalization degree, original area.

\section{Введение}

Изучение процесса адвентизации очень актуально для ботанических садов в связи с их активной интродукционной деятельностью, которая способствует заносу чужеродных видов на новые для них территории, что может создавать угрозу биологическому разнообразию. В связи с этим на V Конгрессе ботанических садов Европы (Хельсинки, 2009 г.) была сформулирована новая задача, стоящая перед европейскими ботаническими садами, — контроль фитоинвазий и предотвращение распространения инвазионных видов растений (Виноградова, 2015). В полной мере это относится к Ботаническому саду Южного федерального университета (БС), который, как и Ростовская область в целом, находится в степной зоне, расположен практически в центре г. Ростова-на-Дону, существует более 90 лет; имеет площадь 160,54 га, более 64 \% которой занято коллекциями живых растений (Вардуни и др., 2016 ; Шмараева, Шишлова, 2018).

\section{Материалы и методы}

Объектом изучения являлись травянистые растения адвентивной флоры Ботанического сада ЮФУ. Изучение процессов синантропизации флоры, в том числе выявление и учёт адвентивных видов, проводились с использованием типовых программ флористических исследований. В результате мониторинга синантропной флоры БС за последние 15 лет и обобщения более ранних исследований (Федяева, 1991; 1994; Федяева, Вахненко, 1998) был составлен список адвентивных травянистых видов (табл.), который документирован гербарием (RWBG, RV). Анализ адвентивной флоры проводился с использованием классификаций и терминов, принятых в работах А. В. Чичёва (Чичёв, 1981), Ю. К. Виноградо- 
вой (Виноградова и др., 2010), О. Г. Барановой (Баранова и др., 2018), Н. В. Овчаровой и Т. А. Терёхиной (Овчарова, Терёхина, 2016). Виды сравнивались по степени натурализации, времени и способам заноса, географическому происхождению. По степени натурализации выделены 4 основные группы: 1) эфемерофиты (ЭФФ) - непостоянные чужеродные виды, имеющие наименьшую степень натурализации; 2) колонофиты (КЛФ) - чужеродные виды, натурализовавшиеся, но не распространяющиеся далеко от мест заноса; 3) эпёкофиты (ЭПФ) - чужеродные виды, активно расселяющиеся по антропогенным местообитаниям; 4) агриофиты (АГФ) - конкурентноспособные чужеродные виды, имеющие высшую степень натурализации, расселившиеся по естественным и полуестественным фитоценозам. По времени заноса выделены группы археофитов (APX - занесены до конца XVI века), неофитов (НФ - занесены в XVII-XIX веках) и эунеофитов (ЭНФ - занесены в XX-XXI веках). По способу иммиграции выделены три группы адвентивных видов: аколютофиты (АКФ) - чужеродные виды, случайно занесённые человеком в результате хозяйственной деятельности и активно (прогрессивно) расселяющиеся по новым антропогенно изменённым местообитаниям благодаря своим биологическим особенностям; ксенофиты (КСФ) - чужеродные виды, случайно занесённые человеком в процессе хозяйственной деятельности в места, удалённые от первоначального ареала, характеризующиеся скачкообразной иммиграцией и низкой степенью натурализации, не образующие фон в отличие от аколютофитов; эргазиофиты (ЭРФ) - одичавшие культурные растения, способные без поддержки человека сохраняться в составе флоры, так называемые «беглецы из культуры».

\section{Результаты и обсуждение}

Ботанический сад Южного федерального университета был создан в 1927 г. на северо-западной окраине г. Ростова-на-Дону на территории, которая включает водораздел между р. Темерник и балкой Сухой Чалтырь, остепнённые склоны правого коренного берега р. Темерник, пойму и русло р. Темерник, а также ручей Гремучий, берущий начало от источника Серафима Саровского и впадающий в $\mathrm{p}$. Темерник (Вардуни и др., 2016). Территория БС в целом относится к Приазовскому ботанико-географическому району, зональная растительность которого определяется как приазовская степь, представляющая собой ксерофитный вариант настоящих красочных разнотравно-типчаково-ковыльных степей (Федяева, 2002). Территория БС за более чем 90 лет его существования была в значительной степени преобразована: большая часть земель была распахана и занята парками, коллекциями древесных и травянистых растений, экспозициями и производственными полями. За долгие годы истории БС использование земельных участков и структура коллекционного фонда неоднократно менялись; были построены новые и снесены старые служебные здания и оранжереи; расширялась дорожно-тропиночная сеть и т.д. Несмотря на активное преобразование БС, на его территории всегда сохранялись и существуют в настоящее время фрагменты естественной растительности: степная (приазовская степь) - по правобережным склонам долины р. Темерник, прибрежноводная - у берегов реки, луговая и лугово-болотная - в пойме реки и ручья Гремучего, водная - в русле реки и ручья. В дендропарках Ботанического сада, заложенных в начале 30-х годов прошлого века, сформировался травяной ярус, сходный с подлеском байрачных лесов Северного Приазовья. Наряду с естественной растительностью в Ботаническом саду возникают временные синантропные сообщества, появление которых связано с разными видами хозяйственной деятельности и негативным влиянием окружающей городской среды на территорию БС. Процессы преобразования территории БС отражаются на количественном составе и структуре его дикорастущей флоры, что подтверждается мониторингом, который проводится с середины 60-х годов прошлого века. В настоящее время дикорастущая флора БС насчитывает 727 видов семенных растений из 89 семейств и 384 родов (Шмараева и др., 2017), в том числе 66 адвентивных видов семенных травянистых растений из 25 семейств и 55 родов (табл.). Адвентивная травянистая флора БС составляет $9,1 \%$ от общего состава дикорастущей флоры БС и 25,0 \% от синантропной флоры БС (Шмараева и др., 2018). Значительная доля адвентивных видов в составе дикорастущей флоры БС объясняется, с одной стороны, разрушением природных экосистем (распашка поймы р. Темерник и др.) и формированием антропогенных экотопов (свалка строительного и бытового мусора и др.), а с другой стороны - фитоценотической активностью натурализовавшихся эргазиофитов. 
Видовой состав и структура адвентивной травянистой флоры Ботанического сада ЮФУ

\begin{tabular}{|c|c|c|c|c|c|}
\hline $\begin{array}{c}\text { № } \\
\text { п.П. }\end{array}$ & Латинское название вида & $\begin{array}{c}\text { Способ } \\
\text { заноса }\end{array}$ & $\begin{array}{l}\text { Время } \\
\text { заноса }\end{array}$ & $\begin{array}{c}\text { Степень } \\
\text { натура } \\
\text { лизации }\end{array}$ & Первичный ареал \\
\hline & Abutilon theophrasti Medik. & ЭРФ & АРФ & ЭПФ & Юго-Вост. Азия \\
\hline & Acalypha australis $\mathrm{L}$. & АКФ & ЭНФ & ЭПФ & $\begin{array}{l}\text { Мал. и Передняя Азия, } \\
\text { Юго-Вост. Азия }\end{array}$ \\
\hline & $\begin{array}{l}\text { Acroptilon repens }(\mathrm{L} .) \text { DC. } \\
\text { [Centaurea repens } \mathrm{L} .]\end{array}$ & АКФ & НФ & ЭПФ & Центр. Азия \\
\hline & Amaranthus albus L. & АКФ & $\mathrm{H} \Phi$ & ЭПФ & Сев. Америка \\
\hline & A. blitoides S. Wats. & АКФ & ЭНФ & ЭПФ & Сев. Америка \\
\hline & A. retroflexus $\mathrm{L}$. & АКФ & НФ & ЭПФ & Сев. Америка \\
\hline & Ambrosia artemisiifolia $\mathrm{L}$. & АКФ & ЭНФ & ЭПФ & Сев. Америка \\
\hline & A. psylostachya DC. & АКФ & ЭНФ & ЭФФ & Сев. Америка \\
\hline & A. trifida $\mathrm{L}$. & АКФ & ЭНФ & ЭФФ & Сев. Америка \\
\hline & Apium graveolens L. & ЭРФ & $\mathrm{AP} \Phi$ & ЭФФ & Средиземноморье \\
\hline & Arrhenatherum elatius (L.) L. \& C. Presl & ЭРФ & ЭНФ & ЭПФ & $\begin{array}{l}\text { Ср. и Атл. Европа, } \\
\text { Средиземноморье }\end{array}$ \\
\hline & Asclepias syriaca L. & ЭРФ & ЭНФ & ЭПФ & Сев. Америка \\
\hline & $\begin{array}{l}\text { Avena persica Steud. [A. sterilis L. subsp. } \\
\text { ludoviciana (Durieu) Gill. \& Magne, } \\
\text { A. ludoviciana Durieu] }\end{array}$ & АКФ & НФ & ЭПФ & Средиземноморье \\
\hline & Bidens frondosa $\mathrm{L}$. & АКФ & $\mathrm{H} \Phi$ & $\mathrm{A} \Gamma \Phi$ & Сев. Америка \\
\hline & Brassica napus L. & ЭРФ & НФ & ЭФФ & Средиземноморье \\
\hline & Cannabis ruderalis Janisch. & АКФ & $\mathrm{AP} \Phi$ & ЭПФ & Центр. и Южн. Азия \\
\hline & $\begin{array}{l}\text { Cardaria draba (L.) Desv. } \\
\text { [Lepidium draba L.] }\end{array}$ & АКФ & АРФ & АГФ & Средиземноморье \\
\hline & $\begin{array}{l}\text { Cenchrus longispinus (Hack.) Fern. } \\
\text { [C. pauciflorus auct. non Benth.] }\end{array}$ & АКФ & ЭНФ & ЭПФ & Сев. Америка \\
\hline & $\begin{array}{l}\text { Conyza canadensis }(\mathrm{L} .) \text { Crongist } \\
\text { [Erigeron canadensis } \mathrm{L} .]\end{array}$ & АКФ & ЭНФ & АГФ & Сев. Америка \\
\hline & Crambe cordifolia Stev. & ЭРФ & ЭНФ & КЛФ & Кавказ \\
\hline & Cuscuta campestris Yunck. & АКФ & НФ & АГФ & Сев. Америка \\
\hline & $\begin{array}{l}\text { Cyclachaena xanthiifolia (Nutt.) Fresen. } \\
\text { [Iva xanthiifolia Nutt.] }\end{array}$ & АКФ & ЭНФ & ЭПФ & Сев. Америка \\
\hline & Cynodon dactylon (L.) Pers. & АКФ & НФ & ЭПФ & $\begin{array}{l}\text { Субтропики Старого и } \\
\text { Нового Света }\end{array}$ \\
\hline & Datura stramonium L. & АКФ & $\mathrm{AP} \Phi$ & ЭПФ & Юго-Вост. Азия \\
\hline & $\begin{array}{l}\text { Dentaria quinquefolia Bieb. [Cardamine } \\
\text { quinquefolia (M. Bieb.) Schmalh.] }\end{array}$ & ЭРФ & ЭНФ & КЛФ & $\begin{array}{l}\text { Кавказ, Средиземномо- } \\
\text { рье, Мал. Азия }\end{array}$ \\
\hline & Digitalis lanata Ehrh. & ЭРФ & НФ & КЛФ & $\begin{array}{l}\text { Ср. Европа, Балканы, } \\
\text { Мал. Азия }\end{array}$ \\
\hline & $\begin{array}{l}\text { Diplotaxis tenuifolia }(\mathrm{L} .) \text { DC. } \\
\text { [Sisymbrium tenuifolium L.] }\end{array}$ & АКФ & ЭНФ & ЭПФ & Средиземноморье \\
\hline & $\begin{array}{l}\text { Echinochloa crusgalli }(\mathrm{L} .) \text { Beauv. } \\
\text { [Panicum crusgalli L.] }\end{array}$ & АКФ & АРФ & АГФ & Центр. и Вост. Азия \\
\hline & Echinocystis lobata (Michx.) Torr. \& A. Gray & $\mathrm{AK} \Phi$ & ЭНФ & ЭПФ & Сев. Америка \\
\hline & Erigeron annuus (L.) Pers. & АКФ & ЭНФ & ЭПФ & Сев. Америка \\
\hline & $\begin{array}{l}\text { Euphorbia chamaesyce L. } \\
\text { [Chamaesyce vulgaris Prokh.] }\end{array}$ & АКФ & ЭНФ & ЭПФ & Средиземноморье \\
\hline & $\begin{array}{l}\text { E. davidii Subils [E. dentata auct. } \\
\text { non Michx.] }\end{array}$ & АКФ & ЭНФ & ЭПФ & Сев. Америка \\
\hline
\end{tabular}


«Проблемы ботаники Южной Сибири и Монголии» - XVIII Международная научно-практическая конференция

Таблица (продолжение)

\begin{tabular}{|c|c|c|c|c|c|}
\hline $\begin{array}{l}\text { № } \\
\text { п.П. }\end{array}$ & Латинское название вида & $\begin{array}{l}\text { Способ } \\
\text { заноса }\end{array}$ & $\begin{array}{l}\text { Время } \\
\text { заноса }\end{array}$ & $\begin{array}{c}\text { Степень } \\
\text { натура } \\
\text { лизации }\end{array}$ & Первичный ареал \\
\hline & Galinsoga parviflora Cav. & AКФ & $\mathrm{H} \Phi$ & ЭПФ & Сев. Америка \\
\hline & Helianthus tuberosus L. & ЭРФ & ЭНФ & КЛФ & Сев. Америка \\
\hline & Hibiscus trionum L. & АКФ & НФ & ЭПФ & Средиземноморье \\
\hline & $\begin{array}{l}\text { Jonoxalis tetraphylla (Cav.) J. Rose } \\
\text { [Oxalis tetraphylla Cav.] }\end{array}$ & КСФ & ЭНФ & ЭФФ & Мексика \\
\hline & Lolium perenne $\mathrm{L}$. & ЭРФ & НФ & КЛФ & $\begin{array}{l}\text { Зап. и Центр. Европа, } \\
\text { Средиземноморье }\end{array}$ \\
\hline & Lunaria аппиа L. & ЭРФ & ЭНФ & ЭФФ & Ср. Европа \\
\hline & $\begin{array}{l}\text { Matricaria recutita } \mathrm{L} . \\
{[\text { Chamomilla recutita }(\mathrm{L} .) \text { Rauschert] }}\end{array}$ & АКФ & АРФ & ЭПФ & Зап. Европа \\
\hline & Medicago sativa $\mathrm{L}$. & ЭРФ & $\mathrm{H} \Phi$ & ЭПФ & Передняя Азия \\
\hline & Oenothera biennis L. & АКФ & $\mathrm{H} \Phi$ & ЭПФ & Сев. Америка \\
\hline & Orobanche cumana Wallr. & АКФ & $\mathrm{H} \Phi$ & ЭПФ & Передняя Азия \\
\hline & $\begin{array}{l}\text { Oxybaphus nyctagineus (Michx.) Sweet } \\
\text { [Mirabilis nyctaginea (Michx.) MacMill.] }\end{array}$ & КСФ & ЭНФ & КЛФ & Сев. Америка \\
\hline & $\begin{array}{l}\text { Parietaria chersonensis (Lang \& Szov.) } \\
\text { Dörfl. }\end{array}$ & КСФ & ЭНФ & КЛФ & $\begin{array}{l}\text { Ср. Европа, Кавказ, } \\
\text { Мал. Азия }\end{array}$ \\
\hline & $\begin{array}{l}\text { Perilla frutescens (L.) Britt. } \\
\text { [P. ocymoides L.] }\end{array}$ & ЭРФ & НФ & ЭФФ & Юго-Вост. Азия \\
\hline & $\begin{array}{l}\text { Potentilla indica (Andr.) Th. Wolf } \\
\text { [Dushesnea indica (Andr.) Focke] }\end{array}$ & ЭРФ & НФ & КЛФ & Юго-Вост. Азия \\
\hline & $\begin{array}{l}\text { Pterotheca sancta (L.) K. Koch } \\
\text { [Lagoseris sancta }(\text { L.) K. Maly] }\end{array}$ & АКФ & НФ & ЭПФ & Средиземноморье \\
\hline & Rubia tinctorum $\mathrm{L}$. & ЭРФ & НФ & КЛФ & $\begin{array}{l}\text { Средиземноморье, } \\
\text { Мал. и Ср. Азия }\end{array}$ \\
\hline & Scabiosa columbaria L. & ЭРФ & ЭНФ & КЛФ & $\begin{array}{l}\text { Кавказ, Ср. Азия, } \\
\text { Ср. Европа, } \\
\text { Средиземноморье }\end{array}$ \\
\hline & Silphium perfoliatum L. & ЭРФ & ЭНФ & КЛФ & Сев. Америка \\
\hline & Smyrnium perfoliatum $\mathrm{L}$. & ЭРФ & ЭНФ & КЛФ & $\begin{array}{l}\text { Кавказ, Средиземно- } \\
\text { морье }\end{array}$ \\
\hline & Solanum cornutum Lam. [S. rostratum Dun.] & АКФ & ЭНФ & ЭПФ & Сев. Америка \\
\hline & $\begin{array}{l}\text { S. schultesii Opiz [S. decipiens Opiz., } \\
\text { S. nigrum subsp. schultesii (Opiz) Wessely] }\end{array}$ & АКФ & НФ & ЭПФ & Зап. Европа \\
\hline & Solidago canadensis $\mathrm{L}$. & ЭРФ & ЭНФ & ЭПФ & Сев. Америка \\
\hline & $\begin{array}{l}\text { Symphyotrichum novae-angliae (L.) G.L. } \\
\text { Nesom [Aster novae-angliae L.] }\end{array}$ & ЭРФ & ЭНФ & КЛФ & Сев. Америка \\
\hline & $\begin{array}{l}\text { S. novi-belgii (L.) G.L. Nesom } \\
\text { [Aster novi-belgii L.] }\end{array}$ & ЭРФ & ЭНФ & КЛФ & Сев. Америка \\
\hline & Thlaspi arvense $\mathrm{L}$. & АКФ & АРФ & ЭПФ & $\begin{array}{l}\text { Ирано-Туранская } \\
\text { область }\end{array}$ \\
\hline & Tulipa tarda Stapf & ЭРФ & ЭНФ & ЭПФ & Тянь-Шань \\
\hline & Veronica persica Poir. ex Lam. & КСФ & $\mathrm{H} \Phi$ & ЭПФ & Юго-Зап. Азия \\
\hline & Vinca major $\mathrm{L}$. & ЭРФ & ЭНФ & КЛФ & $\begin{array}{l}\text { Кавказ, Средиземно- } \\
\text { морье }\end{array}$ \\
\hline & V. minor L. & ЭРФ & ЭНФ & КЛФ & Средиземноморье \\
\hline & $\begin{array}{l}\text { Xanthium albinum (Widd.) Scholz \& Sukopp } \\
{[\text { X. californicum Greene }]}\end{array}$ & АКФ & ЭНФ & ЭПФ & $\begin{array}{l}\text { Южн. и Центр. } \\
\text { Америка }\end{array}$ \\
\hline & X. spinosum $\mathrm{L}$. & АКФ & НФ & ЭПФ & Южн. Америка \\
\hline
\end{tabular}


Таблица (окончание)

\begin{tabular}{|c|l|c|c|c|l|}
\hline $\begin{array}{c}\text { № } \\
\text { п.п. }\end{array}$ & \multicolumn{1}{|c|}{ Латинское название вида } & $\begin{array}{c}\text { Способ } \\
\text { заноса }\end{array}$ & $\begin{array}{c}\text { Время } \\
\text { заноса }\end{array}$ & $\begin{array}{c}\text { Степень } \\
\text { натура } \\
\text { лизации }\end{array}$ & \multicolumn{1}{|c|}{ Первичный ареал } \\
\hline & $\begin{array}{l}\text { Xanthoxalis corniculata } \text { (L.) Small subsp. } \\
\text { corniculata [Oxalis corniculata L.] }\end{array}$ & КСФ & ЭНФ & ЭФФ & Сев. и Южн. Америка \\
\hline $\begin{array}{l}\text { X. dillenii (Jacq.) Holub [Oxalis dillenii } \\
\text { Jacq.] }\end{array}$ & АКФ & ЭНФ & ЭФФ & Сев. Америка \\
\hline $\begin{array}{l}\text { X. stricta } \text { (L.) Small subsp. stricta [Oxalis } \\
\text { stricta } \text { L.] }\end{array}$ & АКФ & ЭНФ & ЭФФ & Сев. и Центр. Америка \\
\hline
\end{tabular}

По способу заноса в структуре адвентивной травянистой флоры преобладают аколютофиты $(56,0 \%)$ и эргазиофиты $(36,4 \%)$, немногочисленной является группа ксенофитов $(7,6 \%)$. В многочисленности группы эргазиофитов проявляется своеобразие адвентивной флоры БС, являющегося на протяжении 90 лет региональным центром интродукции растений. По времени заноса среди адвентивных травянистых растений БС преобладают эунеофиты (36 видов или 54,5 \% от общего состава травянистой фракции адвентивной флоры БС); группа неофитов представлена 22 видами (33,3 \%), а группа археофитов насчитывает 8 видов (или 12,2 \%). Более точная периодизация времени заноса для Нижнего Дона затруднена по причине недостатка сведений о флоре региона в период до XX в. Этим обстоятельством можно отчасти объяснить существенное преобладание эунеофитов над неофитами и археофитами. По степени натурализации в составе адвентивной травянистой флоры БС количественно преобладают эпёкофиты (53,0 \%), колонофиты составляют $24,2 \%$, эфемерофиты - $15,2 \%$, а самая малочисленная группа - агриофиты (7,6 \%). По характеру первичного ареала среди адвентивных травянистых растений БС преобладают североамериканские виды (42,4 \%), особенно высока их доля (40,0 \%) среди склонных к экспансии эпёкофитов. Среди адвентивных травянистых видов Ботанического сада семь таксонов входят в Перечень карантинных объектов (вредителей растений, возбудителей болезней растений и растений-сорняков) на территории РФ. В составе адвентивной травянистой флоры БС имеется один вид - Crambe cordifolia Stev., который включён в Красную книгу РФ (2008). Crambe cordifolia это кавказский вид, который в своё время был объектом интродукционного испытания в БС в составе коллекции кормовых растений, распаханной в начале 80-х годов прошлого века. С тех времён единичные особи этого вида отмечаются в зарослях кустарников недалеко от места расположения бывшей коллекции.

\section{Заключение}

В результате мониторинга был установлен современный видовой состав адвентивной травянистой флоры БС ЮФУ, которая насчитывает 66 видов семенных растений из 55 родов и 25 семейств. В составе адвентивной флоры количественно преобладают по способу заноса аколютофиты, по времени заноса - эунеофиты, по степени натурализации - эпёкофиты, по характеру первичного ареала - североамериканские виды. Среди адвентивных видов БС семь таксонов относятся к карантинным объектам РФ, а Crambe cordifolia включён в Красную книгу РФ (2008). В процессе инвентаризации на территории БС был выявлен новый для Ростовской области адвентивный вид - Parietaria chersonensis (Lang et Szov.) Dörfl.

Исследования проводились при финансовой поддержке Минобрнауки РФ (проект 6.6222.2017/8.9).

\section{ЛИТЕРАТУРА}

Баранова О. Г., Щербаков А. В., Сенатор С. А., Панасенко Н. Н., Сагалаев В. А., Саксонов С. В. Основные термины и понятия, используемые при изучении чужеродной и синатропной флоры // Фиторазнообразие Восточной Европы / Phytodiversity of Eastern Europe, 2018. - T. XII. - № 4. - С. 4-22. 
Вардуни Т. В., Шмараева А. Н., Шишлова Ж. Н., Козловский Б. Л., Федяева В. В. Коллекционная политика Ботанического сада Академии биологии и биотехнологии им. Д. И. Ивановского Южного федерального университета: учебно-методическое пособие. - Ростов-на-Дону: Издательско-полиграфический комплекс КИБИ МЕДИА ЦЕНТРА ЮФУ, 2016. - 168 с.

Виноградова Ю. К. при участии Неywood V. Н. и Sharrock S. Кодекс управления инвазионными чужеродными видами растений в ботанических садах стран СНГ. - М.: ГБС РАН, 2015. - 68 с.

Виноградова Ю. К., Майоров С. Р., Хорун Л. В. Чёрная книга флоры Средней России: чужеродные виды растений в экосистемах Средней России. - М.: ГЕОС, 2010. - 512 с.

Красная книга Российской Федерации (Растения и грибы) / Ред. Л. В. Бардунов, В. С. Новиков. - М.: Т-во научных изданий КМК, 2008. - 855 с.

Овчарова Н. В., Терёхина T. $\boldsymbol{A}$. Инвазивная активность адвентивных видов растений на территории правобережья р. Оби (Алтайский край) // «Проблемы ботаники Южной Сибири и Монголии». - Барнаул: Изд-во Алтайского государственного университета, 2016. - № 15. - С. 349-354.

Федяева В. B. Новые адвентивные виды флоры Ростовской области // Флора Нижнего Дона и Северного Кавказа: структура, динамика, охрана, проблемы использования: Тез. докл. научно-практ. конф. (г. Ростов-на-Дону, октябрь 1991 г.). - Ростов-на-Дону, 1991. - С. 99-100.

Федяева В. В. Проблема антропогенной трансформации флоры Нижнего Дона // Современные проблемы биологии. - Ростов-на-Дону: Науч.-производств. фирма «Камелия», 1994. - С. 51-58.

Федяева В. В. Растительный покров // Природные условия и естественные ресурсы Ростовской области. - Ростов-на-Дону: Батайское книжное изд-во, 2002. - С. 226-282.

Федяева В. В., Вахненко Д. В. К вопросу о синантропизации природной флоры Ботанического сада РГУ // Роль ботанических садов в сохранении биоразнообразия. - Ростов-на-Дону: Изд-во «Гефест», 1998. - С. $139-141$.

Чичёв A. В. Синантропная флора г. Пущино // Экология малого города. - Пущино: ОНТИ НЦБИ АН СССР, 1981. - C. 18-31.

Шмараева А. Н., Шиилова Ж. Н. Роль Ботанического сада Южного федерального университета в сохранении растений // Труды XIV съезда Русского ботанического общества и конференции «Ботаника в современном мире». - Махачкала: АЛЕФ, 2018. - Т. 2. - С. 355-358.

Шмараева А. Н., Шишлова Ж. Н., Кузьменко И. П. Конспект дикорастущей флоры Ботанического сада Южного федерального университета // Труды Ботанического сада Южного федерального университета. Вып. 2: монография / Под ред. Т. В. Вардуни. - Ростов-на-Дону; Таганрог: Издательство Южного федерального университета, 2017. - С. 39-119.

Шмараева А. Н., Шишлова Ж. Н., Кузьменко И. П. Конспект синантропной флоры Ботанического сада Южного федерального университета // Труды Ботанического сада Южного федерального университета. Вып. 3: монография / Под ред. Т. В. Вардуни. - Ростов-на-Дону; Таганрог: Издательство Южного федерального университета, 2018. - С. 21-65. 